\title{
Egg laying site selection by a host plant specialist leaf miner moth at two intra-plant levels in the northern Chilean Atacama Desert
}

\author{
José Storey-Palma ${ }^{1}$, Hugo A. Benítez ${ }^{2,3}$, Enrique A. Mundaca ${ }^{4} \&$ Héctor A. Vargas ${ }^{1,5}$
}

\author{
${ }^{1}$ Departamento de Recursos Ambientales, Facultad de Ciencias Agronómicas, Universidad de Tarapacá, Casilla 6-D, Arica, Chile. \\ eljose49@hotmail.com \\ ${ }^{2}$ Faculty of Life Sciences, The University of Manchester, Manchester M13 9PT, United Kingdom. hugo.benitez@postgrad.manchester.ac.uk \\ ${ }^{3}$ Instituto de Alta Investigación, Universidad de Tarapacá, Casilla 7-D Arica, Chile \\ ${ }^{4}$ Escuela de Agronomía, Facultad de Ciencias Agrarias y Forestales, Universidad Católica del Maule, Casilla 7-D, Curicó, Chile.emundaca@ucm.cl \\ ${ }^{5}$ Corresponding author: havargas@uta.cl
}

\begin{abstract}
Egg laying site selection by a host plant specialist leaf miner moth at two intra-plant levels in the northern Chilean Atacama Desert. The spatial distribution of the immature stages of the leaf miner Angelabella tecomae Vargas \& Parra, 2005 was determined at two intra-plant levels (shoot and leaflet) on the shrub Tecoma fulva fulva (Cav.) D. Don (Bignoniaceae) in the Azapa valley, northern Chilean Atacama Desert. An aggregated spatial pattern was detected for all the immature stages along the shoot, with an age dependent relative position: eggs and first instar larvae were clumped at apex; second, third and fourth instar larvae were mostly found at intermediate positions; meanwhile the spinning larva and pupa were clumped at basis. This pattern suggests that the females select new, actively growing leaflets for egg laying. At the leaflet level, the immature stages were found more frequently at underside. Furthermore, survivorship was higher for larvae from underside mines. All these results highlight the importance of an accurate selection of egg laying site in the life history of this highly specialized leaf miner. By contrast, eventual wrong choices in the egg laying site selection may be associated with diminished larval survivorship. The importance of the continuous availability of new plant tissue in this highly human modified arid environment is discussed in relation with the observed patterns.
\end{abstract}

KEYWORDS. Endophytic; Gracillariidae; hypermetamorphic; Insecta; oviposition.

Egg laying site selection in phytophagous insects is a complex behavior, carried out by many adult insect females, whose importance has been largely acknowledged in the ecology and evolution of Lepidoptera (Thompson \& Pellmyr 1991; Fordyce 2010; Celik 2013; D’Costa et al. 2013; Forister et al. 2013). It may be a critical step to provide an adequate place for the subsequent success of larval development (Rabasa et al. 2005; De Sibio \& Rossi 2012). Egg laying behavior acquires even more importance for species that are endophytic throughout all their larval stages, because in many cases larvae may not be able to switch feeding substrates or to migrate to other places following the egg laying. Larvae are then restricted to remain within the site selected by the adult female until finishing the larval development. This is the case for some species of the diverse micro-moth family Gracillariidae (Lepidoptera), whose early instar larvae are mostly miners on leaves and other plant parts (Kumata 1978; Davis 1987).

The leaf miner Angelabella tecomae Vargas \& Parra, 2005 (Lepidoptera, Gracillariidae, Oecophyllembiinae) is a microlepidopteran species native from the transverse valleys of the hyper arid Atacama Desert of southern Peru and northern Chile, whose larvae are primarily associated with the native shrub Tecoma fulva fulva (Cav.) D. Don (Bignoniaceae) (Vargas \& Parra 2005; Vargas 2010). As typically described for other species of Oecophyllembiinae (Kumata 1998), the hypermetamorphic development of $A$. tecomae is character- ized by the presence of two strikingly different larval forms, both endophytic, with feeding activity restricted only to the early form, namely sap-feeder larva (Vargas \& Parra 2005).

Preliminary field observations on the plant shoots indicate that immature stages of $A$. tecomae are restricted to the leaves near the apex, suggesting that females may prefer new leaves to ensure successful development of larvae (Vargas \& Parra 2005). Thus, this highly specialized larval trophic behavior could be associated with the female's egg laying site selection. On the other hand, observations on egg laying behavior at leaf level show that females of leaf miner species of Gracillariidae tend to prefer either adaxial or abaxial leaf surfaces (Brito et al. 2012, 2013; Mundaca et al. 2013). The oviposition pattern on the abaxial/adaxial surfaces of the leaflets has never been described for A. tecomae.

In order to gain insights on the egg laying behavior by females of $A$. tecomae, the main objective of this study was to describe and analyze the spatial distribution of the immature stages at two intra-plant levels: shoot and leaflets.

\section{MATERIAL AND METHODS}

Study site. The study was carried out in the Azapa valley, which is one of the straight transverse valleys that extend from the Andes ranges to the Pacific Ocean in the northern Chilean Atacama Desert. This area is characterized 
by a tropical hyper desertic bioclimate (Luebert \& Pliscoff 2006). The mean annual precipitation recorded in the area is about $0 \mathrm{~mm}$ (Luebert \& Pliscoff 2006); however the transversal valleys harbor perennial or semi perennial streams as a result of the summer rains that occur in the high plateau and the western slopes of the Andes. This phenomenon allows the presence of native vegetation and agricultural activity along the bottom of the valleys (Vargas \& Parra 2009). Habitat destruction and modification have been extremely intensive in many areas of the transverse valleys, mostly due to the agricultural activity (Luebert \& Pliscoff 2006). As a result, the remaining native vegetation is restricted only to few and scattered patches.

Plant-herbivore system. The ecology of the herbivoreplant system has received little attention so far. Angelabella tecomae has no diapause in the study site, as the immature stages may be found on the host plant throughout the year (Vargas \& Parra 2005). Although an exotic, ornamental host plant (Tecoma stans (L.) Juss. ex Kunth) has been recorded as an alternative host for $A$. tecomae, its presence is restricted to the urban area of the Arica city, and its density is overall low, thus the thriving of the populations of A. tecomae in the study site is largely dependent on T. fulva fulva, which is the only native host plant recorded for the leaf miner so far (Vargas 2010). The leaves of T. fulva fulva are composed by 13-21 little leaflets (Wood 2008), and each mine of A. tecomae is restricted to only one leaflet of the host plant (Vargas \& Parra 2005). Unfortunately, studies that had observed the phenology of the host plant were not found in the literature; however, it has been detected in the field that the greatest vegetative growth of T. fulva fulva occurs in autumn, following the water input prompted by the summer rain floods from the Andes range.

Sampling. In order to determine the spatial pattern of the immature stages of A. tecomae at shoot and leaflet levels, monthly samplings were carried out from May to October 2011 on three marked plants occurring in a patch of native vegetation in the Azapa valley. Three shoots were randomly selected on each of these plants, and one leaf was randomly selected and removed from each node. Selection of T. fulva fulva specimens was carried out to be representative of the general phenological pattern observed for the plant in the locality. The number of plants $(n=3)$ and branches $(n=3)$ by plant was determined based on the time required for one person to carry out all the measurements. Each node was assigned to one of three strata along the shoot: apical (nodes 1-3), middle (nodes 4-6) or basal (nodes 7-9). Leaves were taken to the laboratory to record the number of eggs, larvae and pupae with the aid of a Zeiss ${ }^{\circledR} 9901$ stereomicroscope. The adaxial or abaxial location of each egg or mine in each leaflet of the leaf was also recorded. All the immature stages were kept in 95\% ethanol. Fixed larvae were used for instar determination, which was performed by measuring the maximum head capsule width, according to Storey-Palma et al. (2012), with the aid of an ocular micrometer (precision $=$ $0.01 \mathrm{~mm}$ ) incorporated to the stereomicroscope.
Statistical analyses. The Dispersion Index (Krebs 1999), which is based on the variance to mean ratio, was calculated to analyze the spatial pattern of the immature stages along the shoot. A chi-squared goodness of fit test was performed to analyze the egg laying on adaxial or abaxial surfaces of the leaflet, and a chi-squared test for independence was performed to evaluate if the survivorship of the immature stages was different between leaflet surfaces. All the analyses were performed using the BioEstat 5.0 software (Ayres et al. 2007).

\section{RESULTS}

Spatial pattern along the shoot. We found the distribution of all immature stages to be aggregated along the shoot (Fig. 1; Table I). We also found an age dependent relative position of the immature stages, with eggs and first instar larvae clumped at apex; second, third and fourth instar larvae distributed mostly at intermediate positions along the shoot, and the spinning larva and pupa clumped at basis (Fig. 1).
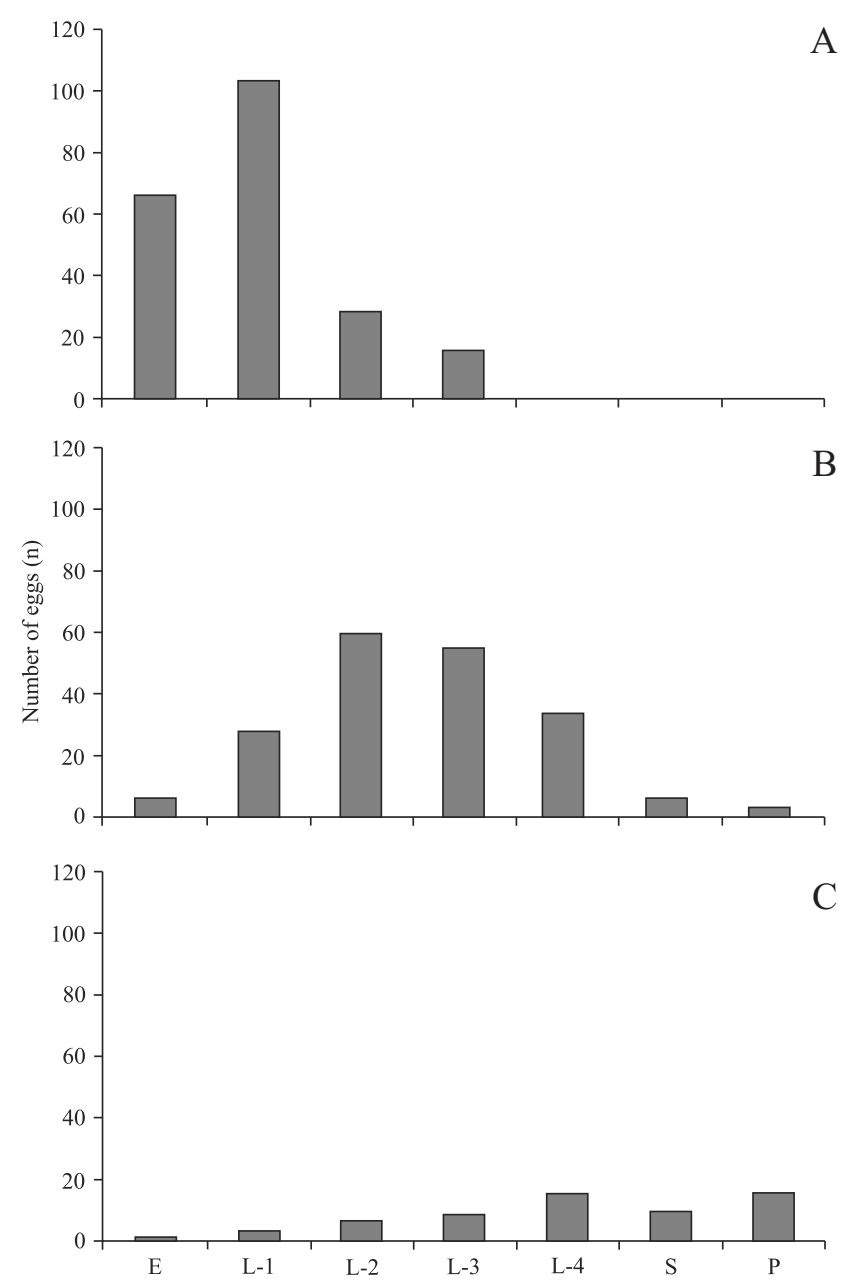

Fig. 1. Number (n) of eggs, larvae and pupae of Angelabella tecomae along the shoots of Tecoma fulva fulva in the Azapa valley, northern Chilean Atacama Desert. (A) shoot apex; (B) shoot middle; (C) shoot basis. E, egg; L-1, first instar larva; L-2, second instar larva; L-3, third instar larva; L-4, fourth instar larva; S, spinning larva; P, pupa. 
Table I. Spatial pattern of the immature stages of Angelabella tecomae along shoots of Tecoma fulva fulva in the Azapa valley, northern Chilean Atacama Desert, based on the Dispersion Index (I)

\begin{tabular}{lrrcc}
\hline \multicolumn{1}{c}{ Stage/Instar } & \multicolumn{1}{c}{$\mathrm{I}$} & \multicolumn{1}{c}{$\chi^{2}$} & $\mathrm{p}$ & Spatial pattern \\
\hline Egg & 53.76 & 107.52 & 0.0000 & Aggregated \\
First instar & 59.26 & 118.52 & 0.0000 & Aggregated \\
Second instar & 22.49 & 44.98 & 0.0000 & Aggregated \\
Third instar & 23.74 & 47.48 & 0.0000 & Aggregated \\
Fourth instar & 17.36 & 54.72 & 0.0000 & Aggregated \\
Spinning larva & 4.75 & 9.50 & 0.0087 & Aggregated \\
Pupa & 11.42 & 22.84 & 0.0018 & Aggregated \\
\hline
\end{tabular}

Leaflet location of eggs and mines. The proportion of eggs (chi-square: 61.493; df: 1; p < 0.0001) and mines (chisquare: 704.665; df: $1 ; \mathrm{p}<0.0001$ ) was not uniformly distributed on both leaflet surfaces. Eggs and mines were more frequently recorded on the abaxial surface (Fig. 2A). The survivorship of larvae was also different among leaflet surfaces. We recorded higher survivorship of larvae on the abaxial surface (chi-square: 12.062; df: 1; $p=0.0005$ ) (Fig. 2B). Furthermore, no pupa was detected in mines on the adaxial surface.


Fig. 2. Distribution and survival of the immature stages of Angelabella tecomae between leaflet surfaces of Tecoma fulva fulva in the Azapa valley, northern Chilean Atacama Desert. A, Proportion of eggs $(n=73)$ and mines $(n=824)$ on the adaxial (black bar) or abaxial (gray bar) surfaces of leaflets. B, Proportion of larval survival (alive = black bar, dead = gray bar) in adaxial $(\mathrm{n}=31)$ or abaxial $(\mathrm{n}=773)$ mines.

\section{DISCUSSION}

Spatial pattern along the shoot. The existence of specific intra-plant spatial patterns of immature stages of insects, e.g. eggs and larvae, has been previously studied
(Kessler \& Baldwin 2002; Queiroz 2002; Leite et al. 2011). Such patterns have been associated to a number of variables, such as predation risk, nutrient availability (Kessler \& Baldwin 2002) and seasonality (Anstey et al. 2002). In our study, the aggregated pattern detected for the immature stages of $A$. tecomae (Fig. 1; Table I) was characterized by an agerelated distribution along the shoot, where early stages are mainly clumped at apex and later stages are located at the basal area of the shoot. Furthermore, larval and pupal development of $A$. tecomae is strictly endophytic, hence the larva is not able to change from one leaflet to another during its development. Pupation also occurs in the leaflet in which the egg was originally laid by the female. Moreover, if a larva is removed from the mine it is not able to build a new mine. Accordingly, the presence of a larva or a pupa in a leaflet constitutes unequivocal evidence that an egg was laid on such leaflet. The age-related distribution along the shoot suggests that females of $A$. tecomae actively select young plant tissue for egg laying. This pattern also confirms previous field observations reported by Vargas \& Parra (2005). Additionally, due to the absence of diapause in A. tecomae in the study area, the evidence of active site selection by the female highlights the importance of the availability of young leaves to allow the larval development throughout the year.

Leaflet location of eggs and mines. The strikingly greater number of eggs and mines on the abaxial leaflet surface indicates that the females of $A$. tecomae actively select this side of the leaflet for egg laying (Fig. 2A). Egg laying patterns among leaf or leaflet surfaces have been already described for some other Neotropical species of Gracillariidae (Davis 1994; Mundaca 2005; Bentancourt \& Scatoni 2007; Kawahara et al. 2009; Davis \& De Prins 2011; Davis \& Wagner 2005, 2011; Davis et al. 2011; Brito et al. 2012, 2013; Mundaca et al. 2013). In terms of the leaf mine, observations indicate that most of the Gracillariidae larvae begin mining the leaf on the same surface where the egg has been deposited, as previously described for A. tecomae (Vargas \& Parra 2005; Vargas 2010). A different pattern has, however, been documented for the Neotropical species Spinivalva gaucha Moreira \& Vargas, 2013, a leaf miner of three Neotropical species of Passiflora (Passifloraceae). In the case of this species, females initially lay the eggs on the abaxial surface of the leaf. Immediately after the eclosion, the first instar larva quickly reaches the palisade parenchyma, and begins the mining process near the adaxial surface (Brito et al. 2013). Thus, the study of the mechanisms underlying egg laying and mine construction patterns deserves further attention.

Interestingly, in the case of $A$. tecomae, the larval survivorship was higher on the same surface (abaxial) that had the higher number of eggs and mines (Fig. 2B). Even more, the absence of pupae in mines on the adaxial surface throughout the sampling period could be an indication of the inadequacy of the mines on this surface for full larval development. Probably, higher sunshine on this leaflet surface could be a factor making it a poor site for rearing of $A$. 
tecomae. Again, the underlying causes of the low egg laying and low larval survivorship in the adaxial surface deserve further studies for this species.

Further remarks. Overall, the data reported here suggest that the presence of new leaves of T. fulva fulva along the year plays a crucial role for the successful development of the life cycle of A. tecomae, as females of this micro-moth actively search new leaves for egg laying. However, as already mentioned, the native vegetation of the valleys of the northern Chilean Atacama Desert is greatly endangered as a result of intensive habitat destruction and modification associated with activities related to agriculture (Luebert \& Pliscoff 2006).

In addition of habitat destruction, the intensive agricultural activity in the Azapa valley is strongly dependent of a high use of water for irrigation, and then the availability of water for the scarce and small remaining patches of native vegetation is extremely low. As a result, plants of T. fulva fulva with a high vegetative vigor are generally scarce in this valley, and, in addition, some plants have its vegetative development so seriously limited that almost no new leaves are produced. Clearly, both situations may have negative consequences on the successful survival of $A$. tecomae, since in practice mean low quantity (reduced number of new leaves) of substrate is available for egg laying and larval development.

Like A. tecomae, many native, little known Lepidoptera of the coastal valleys of the Atacama Desert are associated with relatively ephemeral plant organs, eating on flowers (Vargas \& Parra 2009), new leaves (Vargas \& Moreira 2012) or unripe seeds (Vargas 2011). Furthermore, many of these are strongly associated with their respective host plants, including some cases of monophagy. Obviously, as their host plants are under the same conditions that T. fulva fulva, and then threatened in the same way, a number of negative consequences may be expected for these insects.

Further studies are required to better known the biology of the native Lepidoptera in the coastal valleys of the Atacama Desert to adequately plan the conservation of these species in these extremely vulnerable environments.

\section{ACKNOWLEDGEMENTS}

The authors would like to thank Mariana Lazzaro-Salazar for proof reading this manuscript. Suggestions made by two anonymous reviewers significantly improved the final version of the manuscript. Financial support was obtained from the project DIEXA-UTA 9710-10, Dirección de Investigación, Universidad de Tarapacá.

\section{REFERENCES}

Anstey, L.J., Quiring, D.T. \& Ostaff, D.P. 2002. Seasonal changes in intratree distribution of immature balsam fir sawfly (Hymenoptera: Diprionidae). Canadian Entomologist 134: 529-538.

Ayres, M., Ayres Jr., M., Ayres, D.L. \& Santos, A.A.S. 2007. BioEstat Versão 5.0. Sociedade Civil Mamirauá, MCT-CNPq, Belém, Pará, Brasil.
Bentancourt, C.M. \& Scatoni, I.B. 2007. Morphology and biology of Porphyrosela minuta Clarke 1953 (Lepidoptera: Gracillariidae, Lithocolletinae) in Uruguay. Neotropical Entomology 36: 514-519.

Brito, R., Gonçalves, G.L., Vargas, H.A. \& Moreira, G.R.P. 2012. A new species of Phyllocnistis Zeller (Lepidoptera: Gracillariidae) from southern Brazil, with life-history description and genetic comparison to congeneric species. Zootaxa 3582: 1-16.

Brito, R., Gonçalves, G.L., Vargas, H.A. \& Moreira, G.R.P. 2013. A new Brazilian Passiflora leafminer: Spinivalva gaucha, gen. n., sp. nov. (Lepidoptera, Gracillariidae, Gracillariinae), the first gracillariid without a sap-feeding instar. ZooKeys 291: 1-26.

Celik, T. 2013. Oviposition preferences of a threatened butterfly Leptidea morsei (Lepidoptera: Pieridae) at the western border of its range. Journal of Insect Conservation 17: 865-876.

Davis, D.R. 1987. Gracillariidae, p. 372-374. In: Stehr, F.W. (ed.). Immature Insects. Vol. I, Dubuque, Kendall/Hunt Publishing Company, 975 p.

Davis, D.R. 1994. Neotropical Microlepidoptera XXV. New leaf-mining moths from Chile, with remarks on the history and composition of Phyllocnistinae (Lepidoptera: Gracillariidae). Tropical Lepidoptera 5: 6575.

Davis, D.R. \& De Prins, J. 2011. Systematics and biology of the new genus Macrosaccus with descriptions of two new species (Lepidoptera, Gracillariidae). ZooKeys 98: 29-82.

Davis, D.R. \& Wagner, D.L. 2005. Biology and systematics of the Neotropical leafminer genus Eucosmophora (Lepidoptera: Gracillariidae). Tropical Lepidoptera 13: $1-40$.

Davis, D.R. \& Wagner, D.L. 2011. Biology and systematics of the New World Phyllocnistis Zeller leafminers of the avocado genus Persea (Lepidoptera, Gracillariidae). ZooKeys 97: 39-73.

Davis, D.R., Mc Kay, F., Oleiro, M., Vitorino, M.D. \& Wheeler, G.S. 2011 Biology and systematics of the leafmining Gracillariidae of Brazilian pepper tree, Schinus terebinthifolius Raddi, with descriptions of a new genus and four new species. Journal of the Lepidopterists' Society 65: 61-93.

D’Costa, L., Koricheva, J., Straw, N. \& Simmonds, M.S.J. 2013. Oviposition patterns and larval damage by the invasive horse-chestnut leaf miner Cameraria ohridella on different species of Aesculus. Ecological Entomology 38: 456-462.

De Sibio, P.R. \& Rossi, M.N. 2012. Oviposition of a leaf-miner on Erythroxylum tortuosum (Erythroxylaceae) leaves: hierarchical variation of physical leaf traits. Australian Journal of Botany 60: $136-142$.

Fordyce, J.A. 2010. Host shifts and evolutionary radiations of butterflies. Proceedings of the Royal Society B 277: 3735-3743.

Forister, M.L., Scholl, C.F., Jahner, J.P., Wilson, J.S., Fordyce, J.A., Gompert, Z., Narala, D.R., Buerkle, C.A. \& Nice, C.C. 2013. Specificity, rank preference, and the colonization of a non-native host plant by the Melissa blue butterfly. Oecologia 172: 177-188.

Kawahara, A.Y., Nishida, K.\& Davis, D.R. 2009. Systematics, host plants, and life histories of three new Phyllocnistis species from the central highlands of Costa Rica (Lepidoptera, Gracillariidae, Phyllocnistinae). ZooKeys 27: 7-30.

Kessler, A. \& Baldwin, I.T. 2002. Manduca quinquemaculata's optimization of intra-plant oviposition to predation, food quality, and thermal constraints. Ecology 83: 2346-2354.

Krebs, C.J. 1999. Ecological Methodology. Benjamin-Cummings, 620 p. Kumata, T. 1978. A new stem-miner of alder in Japan, with a review of the larval transformation in the Gracillariidae (Lepidoptera). Insecta Matsumurana, new series 13: 1-27.

Kumata, T. 1998. Japanese species of the subfamily Oecophyllembiinae Réal et Balachowsky (Lepidoptera: Gracillariidae), with description of a new genus and eight new species. Insecta Matsumurana, new series 54: 77-131.

Leite, G.L.D, D’Ávila, V.A., Cerqueira, V.M., Nascimento, A.F. \& Fernandes, G.W. 2011. Spatial distribution of a spherical gall (Hymenoptera, Eulophidae) on Caryocar brasiliense (Caryocaraceae). Revista Brasileira de Entomologia 55: 396-400. 
Luebert, F. \& Pliscoff, P. 2006. Sinopsis bioclimática y vegetacional de Chile. Santiago, Editorial Universitaria, $316 \mathrm{p}$.

Mundaca E.A. 2005. Ampliación de la distribución de Prophyllocnistis epidrymis, Davis (Lepidoptera: Gracillariidae) minador de Drymis winteri (Winteraceae). Noticiario Mensual del Museo Natural de Historia Natural 356: 18-21.

Mundaca, E.A., Parra, L.E. \& Vargas, H.A. 2013. A new genus and species of leaf miner (Lepidoptera, Gracillariidae) for Chile associated to the native tree Lithraea caustica. Revista Brasileira de Entomologia 57: $157-164$.

Queiroz, J.M. 2002. Distribution, survivorship and mortality sources in immature stages of the neotropical leaf miner Pachyschelus coeruleipennis Kerremans (Coleoptera: Buprestidae). Brazilian Journal of Biology 62: 69-76.

Rabasa, S.G., Gutiérrez, D. \& Escudero, A. 2005. Egg laying by a butterfly on a fragmented host plant: a multi-level approach. Ecography 28: 629-639.

Storey-Palma, J., Benítez, H., Parra, L.E. \& Vargas, H.A. 2012. Identification of sap-feeder instars in Angelabella tecomae Vargas \& Parra (Lepidoptera, Gracillariidae) feeding on Tecoma fulva fulva (Bignoniaceae). Revista Brasileira de Entomologia 56: 508-510.
Thompson, J.N. \& Pellmyr, O. 1991. Evolution of oviposition behavior and host preference in Lepidoptera. Annual Review of Entomology 36: $65-89$

Vargas, H.A. 2010. Angelabella tecomae (Lepidoptera: Gracillariidae): an exotic hostplant in northern Chile and first record from Peru. Revista Colombiana de Entomología 36: 340-341.

Vargas, H.A. 2011. A new species of Alucita L. (Lepidoptera: Alucitidae) from northern Chile. Neotropical Entomology 40: 85-88.

Vargas, H.A. \& Parra, L.E. 2005. Un nuevo género y una nueva especie de Oecophyllembiinae (Lepidoptera: Gracillariidae) de Chile. Neotropical Entomology 34: 227-233.

Vargas, H.A. \& Parra, L.E. 2009. Prospección de lepidópteros antófagos asociados a Acacia macracantha Willd. (Fabaceae) en el norte de Chile. Revista Brasileira de Entomologia 53: 291-293.

Vargas, H.A. \& Moreira, G.R.P. 2012. A new species of Bucculatrix Zeller (Lepidoptera: Bucculatricidae) associated with Baccharis salicifolia (Asteraceae) in northern Chile. Zootaxa 3300: 20-33.

Wood, J.R.I. 2008. A revision of Tecoma Juss. (Bignoniaceae) in Bolivia. Botanical Journal of the Linnean Society 156: 143-172.

Received 13 March 2014; accepted 4 June 2014

Associate Editor: Kleber Del Claro 